\title{
Knowledge and Economic Growth: Evidence from Some Developing Countries
}

\author{
Alireza Poorfaraj, Ahmad Jafari Samimi*, Hadi Keshavarz \\ University of Mazandaran, Babolsar, Iran \\ *jafarisa@umz.ac.ir
}

\begin{abstract}
The purpose of this paper is to estimate the impact of Knowledge Index consist of R\&D, human resources and diffusion of ICT on economic growth in developing countries. To do so we have used a sample of 16 developing countries for which the necessary data were available for the period 2000- 2008. In this paper knowledge economy index (R\&D, human resources and diffusion of ICT), Investment (Gross fixed capital formation), general government consumption and labor force considered as explanatory variables and GDP as a dependent variable. Our findings based on panel data econometrics method indicate that the impact of knowledge index on economic growth in the countries under consideration is positive and significance. Therefore, the expansion of knowledge in these countries is suggested.
\end{abstract}

Keywords: Knowledge; Economic Growth; Information \& Communication Technology (ICT); Developing Countries, Panel Data.

\section{Introduction}

Reaching high growth and economic development are among main goals that economic are following. The causes are profits and benefits that to be accomplished in growth process (such as promotion and improve of life level, decreasing poverty and unemployment). For this reason presented different growth theories. The purpose of growth is explaining the determiner factor of growth rates in one country and is the cause of differences of growth rates and per capita income between countries. The neoclassical growth models disregarded the entrepreneur and viewed knowledge as an exogenous factor (Braunerhjelm, 2007). For example, the neoclassical growth model of Solow (1956) focused on exogenous technological or population factors that determine output-input ratio. In this model the balanced path growth is achieved when the output and physical capital grow in tandem at the constant rate of the labor force growth (Jajri and Ismail, 2009). The empirical results of this model indicate that physical capital and labor inputs cannot explain the growth of output completely (Denison, 1962). Also on the basis of this model to give results same growth rate for all economies and this model has not ability to explain to cause of difference long-term growth rate between various countries. In answer to inadequacy of neoclassical growth models Lucas, Romer, Barro and other researchers design patterns that steady state growth can to be accomplished in the way of endogenous.

Lucas (1988) and Romer (1989), has identified a number of factors that determine the growth rate of an economy. Hence, factors such as increasing returns to scale, innovation, openness to trade, international research and development (R\&D), and human capital formation are considered key factors in explaining the growth process (Lucas, 1988 and Turnovsky, 1999). Investments in education, invention, and related knowledge enhancing activities are seen to be the key factors to overcome the impact of the diminishing returns. Technological progress makes it possible to extract greater value from limited resources and sustain the economic growth over the long-term (Romer, 1986 and 1990; Lucas, 1988; and Karagiannis, 2007). The purpose of this study is to examine the relationship between knowledge economy index and economic growth in selected developing countries.In order to we used a panel data set consisting of the log of GDP for the 16 developing countries and a group of indicators (R\&D, human resources and diffusion of ICT) that define the knowledge economy. The main hypothesis of the paper is that the effect of knowledge economy on economic growth is positive and significance. The paper is organized as follows: Section 2 the Knowledge economy framework and economic growth are discussed, section 3 presents the data and estimation method. Finally, Section 4 shows the findings and the main concluding remarks. 


\section{The Knowledge Economy Framework and Economic Growth}

OECD (1996) defines knowledge economy as 'economies which are directly based on the production, distribution and use of knowledge and information'. Also Dahlman and Andersson (2000) defines knowledge economy as 'one that encourages its organizations and people to acquire, create, disseminate and use (codified and tacit) knowledge more effectively for greater economic and social development'. Derek, Chen and Dahlman (2004) described the four pillars of the knowledge economy as follows: Educated and skilled workers who can continuously upgrade and adapt their skills to efficiently create and use knowledge. In the other word a well-educated and skilled population is essential to the efficient creation, acquisition, dissemination and utilization of relevant knowledge, which tends to increase total factor productivity and hence economic growth. Globalization, meanwhile, is bridging the distance between basic skill needs and advanced skills, forcing countries to cover a wide educational band even at low levels of development to catch up with advanced economies and then remain competitive.

An effective innovation system of firms, research centers, universities, consultants, and other organizations that can keep up with the knowledge revolution and tap into the growing stock of global knowledge, assimilate and adapt it to local needs. Also, for most developing countries much of the knowledge and technology that nurtures innovation will originate from foreign sources, entering the country through foreign direct investment (FDI), imports of equipment and other goods, and licensing agreements (The World Bank, 2007). A modern and adequate information infrastructure that can facilitate the effective communication, dissemination, and processing of information and knowledge. ICTs are the essential parts of the knowledge economy and they have been recognized as an effective tool for promoting economic growth and sustainable development. ICT infrastructure refers to the accessibility, reliability and efficiency of computers, phones, television and radio sets, and the various networks that link them. Those can considerably reduce transaction costs by providing ready access to information. The ICT producing sectors have experienced major technological advancements, which have showed up as large gains in total factor productivity at the level of the economy.

\section{Figure 1: Knowledge-Based Economy and Growth}

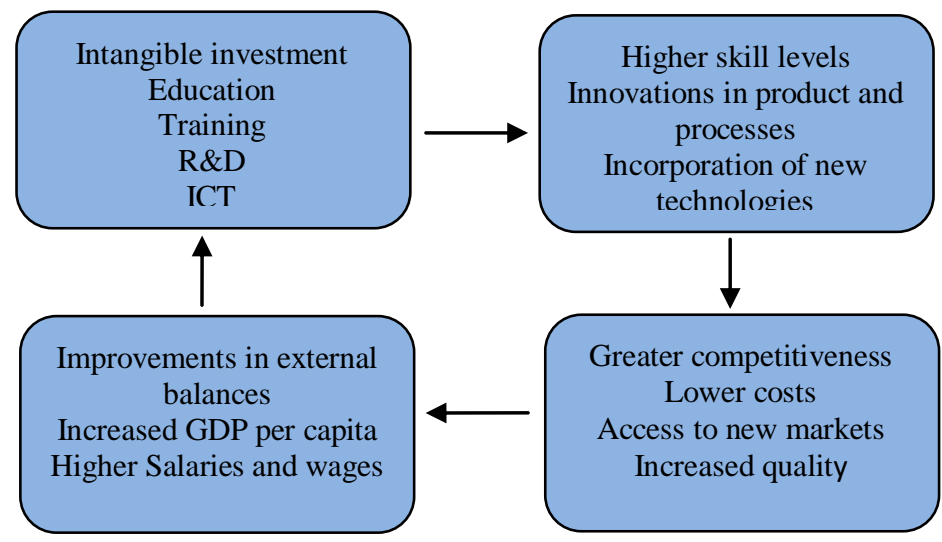

Source: World Bank Institute, Knowledge for Development Program, 2007

\section{Empirical Relationship between knowledge and Economic Growth}

Present section attempts to classify the immense empirical literature relating economic growth with (a) R\&D and investment in innovation (b) human resource development (c) ICT investments and Infrastructure and (d) knowledge and knowledge based economy. In the first group of studies: Both theoretical and empirical literatures have shown that investments in R\&D (research and development) are crucial for economic growth. In the theoretical front, many models (Romer,1990; Grossman and Helpman, 1991; Aghion and Howitt, 1992) illustrate the function of R\&D as a growth engine, and demonstrate the reason why government must have a role in achieving an optimum level of R\&D (Pessoa, 2010). Also most of the empirical studies showed importance of R\&D for economic growth (Griliches, 1992; Jones and Williams, 1998; Falk, 2007 and Goel et al., 2008). In the second group of studies: human capital is included in the productivity estimations as "...knowledge, skills, competencies and other attributes embodied in individuals that are relevant to economic activity..."(OECD, 1998). Most empirical cross country studies that show a positive relationship between human capital and economic growth 
include studies by Denison (1967), Barro (1990), Mankiw et al., (1992), Otani and Villanueva (1990), Hansen and Knowles (1998), Murthy et al., (1997), Barro and Lee (1996), Pritchett (1996) and Agiomirgianakis, at el., (2002).

A single-country study is always considered to have more advantages as compared to the cross-country studies. This is due to the fact that a long time series data for a single country can easily be gathered (Tallman and Wang, 1994). Furthermore the relationship between human capital and economic growth may change over time. Therefore, to capture this relationship, one may need a time series data. Among the studies for a single country that show a positive relationship between human capital and economic growth are Walter and Rubinson (1983); Tallman and Wang (1994); Lau, et al., (1993); Fernandez and Mauro (2000) and Jajri and Ismail (2010). Among the empirical results that show a negative relationship between human capital and economic growth includes studies by Sacerdoti et al., (1998). In the third group of studies: a consensus exists in the important contribution of advanced ICT infrastructure in facilitating access to knowledge and promoting the spread of ideas (Karagiannis, 2007). Early macro level studies, going back to late 1980s and early 1990s, indicated that ICT's share in productivity and economic growth was very small (Roach, 1987; Oliner and Sichel, 1994; Jorgenson and Stiroh, 1995). However, later macroeconomic studies showed that investments in ICT had a considerable effect on economic growth (Jorgenson and Stiroh, 2000; Jorgenson, 2001; Dunn et al., 2004; Piatkowski and Ark 2005; Hosseini and Aghaei, 2009).

Finally, in the third group of studies: Many cross-country empirics have shown that technological differences are the prime cause for differences in GDP per capita (Mankiw, Romer and Weil, 1992). The empirical growth literature emphasizes knowledge and the creation of knowledge via the activities of firms, households and the government in both R\&D and education, as significant drivers for enhancing the level of technology (total factor productivity) (EC, 2005; Karagiannis, 2007). Dogan and at el., 2005 argues that knowledge could become the main engine of growth if the economy establish certain preconditions. These preconditions include a sufficiently high level of quality in human capital stock, a high intensity of domestic innovation and technological adoption, well-established information and communications infrastructure, and the economic and institutional regime to stimulate productivity and economic growth. Also Karagiannis, 2007 find the positive effect knowledge-based economy consist of R\&D effort, quality of human resources, innovation capacity, IT diffusion, access to finance \& information society on economic growth.

\section{Model, Data, and Estimation Methodology}

We study the case of 16 developing countries* and use panel data for the period 2000 -2008. Data on GDP, Investment (Gross fixed capital formation), general government consumption, labor force, R\&D expenditure, ICT expenditureand expenditure of public education in constant (2000 US \$) prices are from WDI and UNESCO. The model to be estimated on panel data for 16 developing countries is based on a simple Cobb-Douglas production function.

Where,

$$
G D P_{i}=\operatorname{EXP}\left(\alpha_{i}\right) K_{i}^{\beta_{1}} L_{i}^{\beta_{2}} G Y_{i}^{\beta_{\pi}} R D_{i}^{\beta_{4}} I C T_{i}^{\beta_{s}} E D U_{i}^{\beta_{i}} U_{i}^{!}
$$

GDP is gross domestic product

$\mathrm{L}$ is labor force

$\mathrm{K}$ is gross fixed capital formation

GY is Exports of goods and services

$\mathrm{RD}$ is expenditure of Research and Developing

ICT is expenditure of Information and Communication Technology

EDU is expenditure of public education.

The model can be rewritten as follows:

$$
\begin{aligned}
\ln \left(G D P_{i}\right)= & \alpha_{i}+\beta_{1} \ln \left(K_{i}\right)+\beta_{2} \ln \left(L_{i}\right)+\beta_{3} \ln \left(G Y_{i}\right)+\beta_{4} \ln \left(R D_{i}\right)+\beta_{5} \ln \left(I C T_{i}\right)+ \\
& \beta_{6} \ln \left(E D U_{i}\right) \varepsilon_{i}
\end{aligned}
$$

\footnotetext{
${ }^{*}$ The countries are Argentina, Chile, Colombia, Hungary, India, Indonesia, Iran Islamic Rep, Malaysia, Mauritius, Mexico, Peru, Philippines, Poland, Slovenia, South Africa, Thailand, and Turkey.
} 
Tables 1: panel data estimation results for 2000-2008

\begin{tabular}{lllll}
\hline Variables & \multicolumn{2}{c}{$\begin{array}{c}\text { Fixed effect } \\
\text { t-Statistic }\end{array}$} & \multicolumn{2}{c}{ Random effect } \\
& \multicolumn{1}{c}{ Coefficient } & \multicolumn{1}{c}{ t-Statistic } \\
\hline Constant & $3.856032^{*}$ & 20.43151 & $2.940577^{*}$ & 12.00117 \\
$\ln \mathrm{l}$ & $0.22233^{*}$ & 17.33233 & $0.218266^{*}$ & 11.89428 \\
$\ln \mathrm{l}$ & $0.254081^{*}$ & 10.56038 & $0.353173^{*}$ & 10.83283 \\
$\operatorname{lnGY}$ & $0.177465^{*}$ & 12.19864 & $0.161875^{*}$ & 7.548593 \\
$\ln \mathrm{RD}$ & $0.032703^{*}$ & 2.126062 & $0.034522^{* *}$ & 1.654986 \\
LnICT & $0.022389^{*}$ & 3.856117 & $0.015837^{* *}$ & 1.883161 \\
LnEDU & -0.0031 & -0.37561 & 0.011562 & 0.801166 \\
R2 & 0.99 & & 0.95 & \\
F-statistic & 41298.9 & & 337.7 & \\
\hline
\end{tabular}

*Indicates significance at $5 \%$ level.

**Indicates significance at $10 \%$ level.

\section{Findings and Concluding Remark}

Based on regression results in table (1) all parameters estimated except education have the expected signs and are positive and statistically significance. Regarding the impact of knowledge economy indicators on economic growth the table indicates that the coefficient is positive and statistically significance at a 10 percent level. In other word the results support the importance role of the knowledge economy in economic growth of the countries under consideration. Therefore, it is suggested that the developing countries improve their performances in the so-called knowledge economy indicators such as the Educated and skilled workers, effective innovation system, modern and adequate information infrastructure, increase investment in Education, Training, R\&D and ICT in order to achieve higher economic growth.

\section{References}

Aghion, P. and Howitt, P. (1992). A model of growth through creative destruction. Econometrica, 60(2): 323-351.

Agiomirgianakis, G., Asteriou, D. and Monastiriotis, V. (2002). Human Capital and Economic Growth Revisited: A Dynamic Panel Data Study. International Advances in Economic Research. 8(3): 177187.

Barro, R. J. (1990). Government spending in a single model of endogenous growth. Journal of Political Economy, 98: 103-25.

Barro, R. and Lee, J. W. (1996). International measures of schooling years and schooling quality. American Economic Review, 80: 218-28.

Braunerhjelm, P. (2007). Entrepreneurship, Innovation and Economic Growth - past experience, current knowledge and policy implications. CESIS Electronic Working Paper Series, No 224.

Dahlman, C. J. and Andersson, T. (2000). Korea and the Knowledge-based Economy: Making the Transition. The World Bank, Washington DC, USA.

Denison, E. F. (1962). The source of economic growth in the U. S. and the alternative before U. S. New York: Committee for Economic Development.

Denison, E. F. (1967). Why Growth Rates Differ. Washington D.C. Brookings Institution.

Derek, H., Chen, C. and Dahlman C. J. (2004). Knowledge and Development, the World Bank, World Bank Policy Research Working Paper, August 2004.

Dunn, W. E., Doms, M. E., Oliner, S. D. and Sichel D. E. (2004). How Fast Do Personal Computers Depreciate? Concepts and New Estimates. Tax Policy and the Economy 18, ed. James Poterba. Cambridge, MA: MIT Press.

Falk, M. (2007). R\&D spending in the high-tech sector and economic growth. Research in Economics, 61: 140-147.

Fernandez, E. and Mauro, P. (2000). The role of human capital in economic growth: The case of Spain. IMF Working Paper, $100(8):$ 1-27.

Goel, R. K., Payne, J. E. and Ram, R. (2008). R\&D expenditures and U.S. economic growth: A disaggregated approach. Journal of Policy Modeling, 30: 237-250.

Griliches, Z. (1992). The search for R\&D spillovers. Scandinavian Journal of Economics, 94: 29-47. 
Grossman, G. and Helpman, E. (1991). Innovation and Growth in the Global Economy. MIT Press, Cambridge, MA.

Hansen, P. and Knowles, S. (1998). Human capital and return to scale. Journal of Economic Studies, 25: 118-123.

Hosseini, N. E. and Aghaei, M. (2009). The Effect of ICT on Economic Growth: Further Evidence. International Bulletin of Business Administration, 5: 46-56.

Jajri, I. and Ismail, R. (2009). Technical Progress and Labor Productivity in Small and Medium Scale Industry in Malaysia. European Journal of Economics, Finance and Administrative Sciences. 15: 199-208.

Jajri, I. and Ismail, R. (2010). Impact of labor quality on labor productivity and economic growth. African Journal of Business Management, 4(4): 486-495.

Jones, C. I. and Williams, J. C. (1998). Measuring the social return to R\&D. The Quarterly Journal of Economics, 113: 1119-1135.

Jorgenson, D. W. and Stiroh, K. J. (2000). U.S economic growth at the industry level. American Economic Review, 90: 161-168.

Jorgenson, D. W. and Stiroh, K. J. (1995). Computers and Growth. Economics of Innovation and New Technology, 3: 295-316.

Jorgenson, D. W. (2001). Information Technology and the U.S. Economy. American Economic Review, 91(1): 1-32.

Karagiannis, S. (2007). The Knowledge-Based Economy, Convergence and Economic Growth: Evidence from the European Union. Centre of Planning and Economic Research, Athens, Greece, 9: 1-40.

Lau L. J., Jamison, D. T. and Rivkin, S. (1993). Education and economic growth. Journal of Economic Development, 14: 45-70.

Lucas, R. (1988). One the mechanics of economic development. Journal of Monetary Economics, 23: 3-42.

Mankiw, N. G., Romer, D. Weil, D. N. (1992). A Contribution to the empirics' economic growth. The Quarterly Journal of Economics, 107(2): 407-437.

Murthy, N., Vasudeva, R. and Chien, IS. (1997). The empirical of economic growth for OECD Countries: Some new findings. Economics Letters, 55: 425-429.

OECD, (1996). The Knowledge Based Economy. Paris: OECD.

OECD (1998b). Human Capital Investment - An International Comparison, Paris.

Oliner, S. D. and. Sichel, D. E. (1994). Computers and Output Growth Revisited: How Big is the Puzzle?" Brookings Papers on Economic Activity 2: 273-317.

Oliner, S. D. and Daniel E. S. (2000). The Resurgence of Growth in the Late 1990s: Is Information Technology the Story? Journal of Economic Perspectives, 14(4): 3-22.

Otani, I. and Villanueva, D. (1990). Long-term growth in developing countries and its determinants: An Empirical Analysis World Development. 18(6), 769-783.

Pessoa, A. (2010). R\&D and economic growth: How strong is the link? Economics Letters, 107: 152-154.

Piatkowski, M. and Ark, V. B. (2005). ICT and Productivity Growth in Transition Economics: Two Phase Convergence and Structural Reforms. TIGER Working Paper Series, No 72.

Pritchett, L. (1996). Where has all the education gone? World Bank Working Paper. No 1581.

Roach, S. S. (1991). Services under Siege: the Restructuring Imperative. Harvard Business Review, 392: 8292.

Romer, P. (1989). Capital Accumulation and Long-Run Growth," in Modern Business Cycle Theory, edited by R. J. Barro, MA Cambridge, MA: Harvard University Press.

Romer, P. (1990). Endogenous technological change. Journal of Political Economy, 98: 71-102.

Romer, P. (1989). The Origins of endogenous Growth. Journal of Economic Perspectives, 8: 3-22.

Sacerdoti, E., Brunshwig, S. and Tang, J. (1998). The impact of human capital on growth: evidence from West Africa. IMF Working Paper, 98(162):1-32.

Solow, M. R. (1956). A Contribution to the Theory of Economic Growth. The Quarterly Journal of Economics, 70(1): 65-94.

Tallman, E. W. and Wang, P. (1994). Human capital and endogenous growth. Evidence from Taiwan, Journal of Monetary Economics, 34: 101-124.

Turnovsky, S. (1999). Economic Growth in Open Economies. Journal of Economic Dynamics and Control, 23: $671-73$.

Walter, P. B. and Rubinson, R. (1983). Educational expansion and economic output in the U. S. 1890-1969: A production function analysis, American Sociological Review, 48: 480-493.

World Bank Institute, (2007): "Knowledge for Development Program", Building knowledge economies: advanced strategies for development. 